\title{
A NOTE ON THE CONSEQUENCES OF A HOT MITOCHONDRION: SOME RECENT DEVELOPMENTS AND OPEN QUESTIONS ${ }^{1}$
}

\author{
Peyman Fahimi ${ }^{\text {a,b }}$, Mohamed A. Nasr ${ }^{\text {a,c }}$, Lázaro A. M. Castanedo ${ }^{\text {a,d }}$, Youji Cheng ${ }^{\text {a,d }}$, \\ Cyrus A. Toussi ${ }^{\mathrm{a}, \mathrm{e}}$, Chérif F. Matta ${ }^{\mathrm{a}-\mathrm{d}, \mathrm{f}, *}$ \\ ${ }^{a}$ Department of Chemistry and Physics, Mount Saint Vincent University, Halifax, Nova Scotia, Canada B3M2J6 \\ ${ }^{b}$ Département de chimie, Université Laval, Québec, Québec, Canada G1V $0 A 6$ \\ ${ }^{c}$ Center of Excellence for Stem Cells and Regenerative Medicine (CESC), Zewail City of Science and \\ Technology, 6th of October City 12588, Egypt \\ ${ }^{d}$ Department of Chemistry, Saint Mary's University, Halifax, Nova Scotia, Canada B3H3C3 \\ ${ }^{e}$ Department of Biomedical Engineering, Hakim Sabzevari University, Sabzevar, Iran \\ ${ }^{f}$ Department of Chemistry, Dalhousie University, Halifax, Nova Scotia, Canada B3H4J3 \\ *Tel.:+1-(902)-457-6142; Fax:+1-(902)-457-6134; E-mail: cherif.matta@msvu.ca \\ Submitted November 14, 2019 \\ Accepted January 16, 2020
}

Background: Chrétien and co-workers (PLOS Biology. 2018;16(1):e2003992) recently suggested that the mitochondrion might possibly be hotter than its surrounding (by as much as $10^{\circ} \mathrm{C}$ ).

Objectives: To examine the validity of this claim and review the possible implications and repercussion of such a claim - if true - on some aspects of mitochondrial biochemistry and biophysics.

Results: Both the chemical gradient and the electrical gradient Gibbs energy terms in the central equation of chemiosmotic theory are temperature dependent, the first explicitly and the second implicitly. A hotter mitochondrion - as claimed - would imply a 3\% correction in the chemical gradient term, but we cannot estimate the corresponding effect on the electrical term at this time since the functional dependence of the voltage on the temperature is not known to the best of the authors' knowledge. Further, if this claim is true and to the extent claimed $\left(10^{\circ} \mathrm{C}\right)$, this may imply some heat-engine character for mitochondrial thermodynamic operation albeit this may only represent $4 \%$ at most.

Conclusions: Doubts and criticisms regarding the suggestion of a hotter mitochondrion have been raised and are briefly discussed. These doubts are contrasted with some data and considerations that support the claim of a hotter mitochondrion. It is concluded that the mitochondrion is probably hotter than its environment but not to the extent claimed by Chrétien et al. and that the thermodynamic efficiency and the mode of operation of the mitochondrion as an electrochemical battery are very slightly perturbed by even the maximum claimed revision of the temperature of its operation.

KEY WORDS: hot mitochondrion; mitochondrial biophysics; ATP synthase; Maxwell demon; chemiosmotic theory.

\section{ЩОДО ГАРЯЧИХ МІТОХОНДРІЙ: ДЕЯКІ НОВІ РОЗРОБКИ ТА ВІДКРИТІ ПИТАННЯ} Пейман Фахими ${ }^{\text {a,b }}$, Мохамед А. Наср ${ }^{\text {a,c }}$, Лазаро А. М. Кастанедо ${ }^{a, d}$, Йодзі Ченг ${ }^{\mathrm{a}, \mathrm{d}}$, Сайрус А. Туссі ${ }^{\mathrm{aee}}$, Шериф Ф. Матта ${ }^{\mathrm{a}-\mathrm{d}, \mathrm{f},{ }^{*}}$

${ }^{a}$ Факультет хімї та фізики, Університет Маунт-Сент-Вінсент, Галіфакс, Нова Шотландія, Канада Взм2Ј6 ${ }^{b}$ Кафедра хімії, Університет Лаваль, Квебек, Квебек, Канада G1V $0 A 6$

${ }^{c}$ Центр передового досвіду зі стовбурових клітин і регенеративної медицини (CESC), Місто науки і техніки Зевейл, Місто імені 6 жовтня 12588, Сгипет

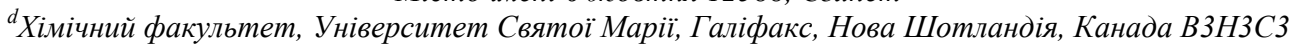

\footnotetext{
1 This communication is patterned after the presentation of the corresponding author (C.F.M.) entitled "Controlled Thermogenesis in the Mitochondrion" presented at the $6^{\text {th }}$ International Conference on Nanobiophysics: Fundamental and Applied Aspects (NBP-2019) held at the Institute of Physics of the National Academy of Sciences of Ukraine in Kyiv (Ukraine), 1-4 October 2019.
}

(C) Peyman Fahimi, Mohamed A. Nasr, Lázaro A. M. Castanedo, Youji Cheng, Cyrus A. Toussi, Chérif F. Matta, 2020 


\author{
${ }^{e}$ Кафедра біомедичної інженерії, Університет Хакім Сабзевари, Сабзевар, Іран \\ ${ }^{f}$ Хімічний факультет, Університет Далхаузі, Галіфакс, Нова Шотландія, Канада ВзН4J3 \\ ${ }^{*}$ Тел.: + 1- (902) -457-6142; Факс: + 1- (902) -457-6134; E-mail: cherif.matta@msvu.ca
}

\begin{abstract}
Актуальність. Кретьєн та його колеги (Chrétien et al., PLOS Biology. 2018; 16(1): е2003992) нещодавно припустили, що мітохондрії можуть бути теплішими, ніж їх оточення на цілих $10^{\circ} \mathrm{C}$.
\end{abstract}

Мета роботи: розглянути обгрунтованість цього твердження та, якщо воно вірне, переглянути його можливі наслідки для деяких аспектів біохімії і біофізики мітохондрій.

Результати. У центральному рівнянні хеміосмотичної теорії обидва члени, як хімічного, так i електричного, градієнтів енергії Гібса залежать від температури: перший явно та другий неявно. Гаряча мітохондрія, як стверджується, передбачає 3\% поправку для хімічного градієнта, проте наразі ми не можемо оцінити відповідний внесок в електричну складову, оскільки, як відомо авторам, функціональна залежність напруги від температури не відома. Крім того, якщо це твердження вірно і відповідає заявленому значенню у $10^{\circ} \mathrm{C}$, це може означати певну подібність до теплового двигуна для виконання мітохондрією термодинамічної роботи, хоча цей внесок може складати не більше ніж $4 \%$.

Висновки. Висловлено та коротко обговорено сумніви і критичні зауваження щодо припущення існування гарячих мітохондрій. Ці сумніви суперечать деяким даним і міркуванням, що підтверджують ідею про гарячі мітохондрії. Робиться висновок, що мітохондрії, ймовірно, є більш теплими, ніж навколишнє внутрішньоклітинне середовище, але не в тій мірі, як стверджують Кретьєн зі співавторами, та що термодинамічна ефективність і спосіб функціонування мітохондрії як електрохімічної батареї дуже незначно змінюються навіть при максимальній заявленій зміні ії робочої температури.

КЛЮчОВІ СЛОВА: гаряча мітохондрія, біофізика мітохондрій, АТФ-синтаза, демон Максвелла, хеміосмотична теорія.

К ВОПРОСУ О ГОРЯЧИХ МИТОХОНДРИЯХ: НОВЫЕ РАЗРАБОТКИ И ОТКРЫТЫЕ ВОПРОСЫ

\author{
Пейман Фахими ${ }^{\mathrm{a}, \mathrm{b}}$, Мохамед А. Наср, \\ Ёдзи Ченг ${ }^{\mathrm{a}, \mathrm{d}}$, Сайрус А. Тусси ${ }^{\mathrm{a}, \mathrm{e}}$, Шериф Ф. Матта ${ }^{\mathrm{a-d}, \mathrm{f}, *}$ \\ ${ }^{a}$ Кафедра химии и физики, Университет Маунт-Сент-Винсент, Галифакс, Новая Шотландия, Канада В3М2Ј6 \\ ${ }^{b}$ Кафедра химии, Университет Лаваль, Квебек, Квебек, Канада GIV 0 A6 \\ ${ }^{c}$ Центр передового опыта по стволовым клеткам и регенеративной медицине (CESC), Город науки и техники \\ Зевейл, Город имени 6 октября 12588, Египет \\ ${ }^{d}$ Химический факультет, Университет Святой Марии, Галифакс, Новая Шотландия, Канада ВзНЗСЗ \\ ${ }^{e}$ Кафедра биомедииинской инженерии, Университет Хаким Сабзевари, Сабзевар, Иран \\ ${ }^{f}$ Химический факультет, Университет Далхаузи, Галифакс, Новая Шотландия, Канада ВзН4Ј3 \\ *Тел.: + 1-(902)-457-6142; Факс: +1-(902)-457-6134; e-mail: cherif.matta@msvu.ca
}

Актуальность. Кретьен с соавторами (Chrétien et al., PLOS Biology. 2018;16(1):e2003992) недавно предположили, что митохондрии могут быть теплее, чем окружающая среда на целых $10^{\circ} \mathrm{C}$.

Цель работы: Рассмотреть обоснованность этого утверждения и, если оно верно, пересмотреть его возможные последствия для некоторых аспектов биохимии и биофизики митохондрий.

Результаты. В центральном уравнении хемиосмотической теории оба члена, как химического, так и электрического, градиентов энергии Гиббса зависят от температуры: первый явно и второй неявно. Горячая митохондрия, как утверждается, подразумевает 3\%-ю поправку для химического градиента, однако мы не можем сейчас оценить соответствующий вклад в электрическую составляющую, поскольку функциональная зависимость напряжения от температуры, насколько известно авторам, не установлена. Кроме того, если это утверждение верно и разность температур соответствует заявленному значению в $10^{\circ} \mathrm{C}$, то можно предположить существование некоего подобия теплового двигателя для выполнения митохондрией термодинамической работы, хотя этот вклад может составлять не больше чем $4 \%$.

Выводы. Были выдвинуты и кратко обсуждены сомнения и критические замечания относительно предположения о горячих митохондриях. Эти сомнения противоречат некоторым данным и соображениям, которые поддерживают идею о горячих митохондриях. Делается вывод, что митохондрия, вероятно, является более теплой, чем окружающая ее среда, но не в той степени, как утверждают Кретьен и соавт., и что термодинамическая эффективность и способ функционирования митохондрии в качестве электрохимической батареи нарушаются весьма незначительно даже при максимальном заявленном изменении ее рабочей температуры.

КЛЮЧЕВЫЕ СЛОВА: горячая митохондрия, биофизика митохондрий, АТФ-синтаза, демон Максвелла, хемиосмотическая теория. 
Since Philip Siekevitz coined the term, the mitochondrion has been recognized as the "powerhouse of the cell" [1]. A thermal power-plant's efficiency $\eta$ is given by the celebrated Carnot formula:

$$
\eta=1-\left(\frac{T_{\text {cold }}}{T_{\text {hot }}}\right) \text {. }
$$

However, the living cell is considered to operate under isothermal conditions (at a temperature of $37^{\circ} \mathrm{C}$ in humans), even though this view may require minor revision. For an isothermal system, the efficiency can be described by the more general equation:

$$
\eta=\frac{w}{\Delta G(T)}=\frac{w}{\Delta H-T \Delta S}
$$

that is, the ratio of useful work $w$ (or energy containing product such as ATP) over the energy content of ingested foodstuffs.

Mitochondrial energy efficiency is important in characterizing and understanding a number of diseases (e.g. in insulin resistance of cells that results in diabetes mellitus [2], or in the well-known switching of metabolism to glycolysis in cancerous cells known as the Warburg effect) and in understanding thermodynamic aspects of biological evolution [3]. Thermodynamic efficiency clearly depends on temperature through $\Delta G$ 's dependence on the temperature of the surrounding thermal bath in isothermal conditions (Eq. (2)) or on the difference in the temperatures of two compartments in the case of a heat engine when a temperature gradient exists (Eq. (1)). Hence, knowledge of the temperature of operation of the mitochondrion and its surroundings is crucial for a proper understanding of its thermodynamic efficiency.

Using a molecular thermometer mito thermo yellow (MTY) that distributes preferentially inside the mitochondrial matrix [4], Chrétien et al. have recently suggested that the mitochondrion operates at temperatures that are higher than their immediate cellular surroundings, temperatures that can perhaps fetch as high as $50^{\circ} \mathrm{C}$ [5]. Doubts on the interpretation of the experimental data have been cast by Lane [6] to the effect that it may be just a matter of degree, that is, the mitochondrion is probably hotter than the rest of the cell but perhaps not as hot as Chrétien et al. claim.

\section{PROBLEM FORMULATION}

Other concerns have been raised against the used MTY by Arai et al. who suggested that MTY fluorescence signal can be affected by several parameters that include $\mathrm{pH}$, oxygen species, membrane potential, viscosity, and ionic strength [4]. Moreover, MTY dye has showed different sensitivity depending on the tissue type. Another concern is the possibility of MTY dye leakage from mitochondria which may give false positive results of increased mitochondrial temperature. This leakage has been attributed to the non-covalent bonding of MTY to the mitochondrial aldehyde dehydrogenase [4]. Although it is known that MTY dye binds to mitochondrial aldehyde dehydrogenase, its precise location inside the mitochondrial matrix is not exactly known [7]. Other possible caveats have been discussed by Lane such as the possibility of MTY fluorescence quenching at high concentrations [6].

The experimental design by Chrétien et al. has tackled most of the previously mentioned concerns showing, for example, that the decrease in fluorescence was specific to the increased mitochondrial temperature [5]. Other conceptual and theoretical concerns can be raised not against the increase in the mitochondria temperature but against the extent of this increase. Baffou et al. have previously shown that that the maximal temperature increase by endogenous thermogenesis in cells cannot exceed $10^{-5} \mathrm{~K}$ for the entire cell and $10^{-4} \mathrm{~K}$ for mitochondria, later known as the $10^{5}$ gap, as a critique for reported temperature elevations 
measured by thermosensitive probes [8]. However, other authors have criticized some points that were overlooked by Baffou et al. and which may make the $10^{5}$ gap unnecessarily true under realistic biological conditions and approximations $[9,10]$.

Lane applied the $10^{5}$ gap criticism of endogenous thermogenesis to the $10^{\circ} \mathrm{C}$ increase in mitochondrial temperature, doubting the correctness of the $10^{5}$ gap calculations and at the same time doubting the $10^{\circ} \mathrm{C}$ increase value [6]. Finally, a conceptual problem was raised by Lane about what the meaning of temperature measurement in mitochondria if a steep temperature gradient $\left(10^{\circ} \mathrm{C}\right)$ exists since - by definition - temperature is the average kinetic energy [6].

Much more dramatically, and based on an order of magnitude estimation of the power consumption of a growing bacterial cell and the thermal conductivity of water, Sear challenges the Chrétien et al.'s finding and arrives at a maximum estimated energy flux of 1 $\mathrm{W} / \mathrm{m}^{2}$ which translates into a temperature gradient of a maximum of $1 \mathrm{~K} / \mathrm{m}$, that is, a maximum gradient of the order of a $\mu \mathrm{K}$ across the dimensions of the cell [11]. Sear's challenge is to essentially falsify the proposition of any notable temperature difference between cell compartments since at the most these would be in the micro-Kelvin range.

However, the fact remains as to how can one explain away Chrétien et al.'s results? And also the fact that other experimenters have come to similar conclusions, albeit not as dramatic as Chrétien et al.'s $10^{\circ} \mathrm{C}$ gradient. For instance, Shen et al. use rhodamine B methyl ester dye as a mitochondrial thermometer to establish that the natural anti-inflammatory autacoid prostaglandin $\mathrm{E}_{2}\left(\mathrm{PGE}_{2}\right)$ can decrease the intracellular temperature of hepatocytes [12]. These workers argue that Chrétien et al.'s findings are consistent with theirs since $\mathrm{PGE}_{2}$ downregulates metabolism and, hence, heat production in the hepatocites [12]. Using fluorescent thermometry, Okabe et al. report a $1^{\circ} \mathrm{C}$ gradient between the cell nucleus and the cytosol $[13,14]$. The presumed existence of (significant) intracellular temperature gradients motivated researchers to develop molecular thermometers that can penetrate mammalian cells and yeast (see for example Ref. [15]).

\section{DISCUSSION}

If indeed the mitochondrion is hotter than its surroundings, even by a few degrees, then some of our understanding of mitochondrial biochemistry and biophysics may possibly need to be slightly revisited. We insist on the adjective "slight" since even in the most extreme case of $\sim 10^{\circ} \mathrm{C}$ temperature gradient, this would translates through Eq. (1) into a theoretical maximum of only $\sim 4 \%$ revision of the efficiency, while this number drops to a maximum of $\sim 0.3 \%$ for a $1{ }^{\circ} \mathrm{C}$ gradient which is, at best, a perturbation that is much less than any hopedfor precision of intracellular conditions. One has also to consider the local random fluctuation of temperature in very small confined spaces in the spatial dimensions [16] as well as in the temporal dimension [17].

Hence, and more explicitly, such a revision may include a reconsideration of the explicit dependence of the first term $\left(\Delta G_{\text {chem. }}\right.$. $)$ in the Gibbs energy expression of the chemiosmotic energy (Eq. (1)) on $T$ and also the indirect effect of the temperature on the second electric term $\left(\Delta G_{\text {elec. }}\right)$ :

$$
\Delta G=\underbrace{2.3 n R T \Delta \mathrm{pH}}_{\Delta G_{\text {chem. }}}+\underbrace{n \mathscr{F} \Delta \psi}_{\Delta G_{\text {clec. }}},
$$

where $\Delta \mathrm{pH}=\mathrm{pH}_{\text {in }}-\mathrm{pH}_{\text {out }}$, and Faraday's constant $\mathscr{F}=96.485 \mathrm{~kJ} \cdot \mathrm{V}^{-1} \cdot \mathrm{mol}^{-1}$, which yields for a $\Delta \mathrm{pH}=1$ unit and $37^{\circ} \mathrm{C}$ :

$$
\Delta G=2.3 R T+\mathscr{F}(0.25 \mathrm{~V}) \approx \underbrace{6 \mathrm{~kJ}}_{\substack{\Delta G_{\text {chem. }} \\
(20 \%)}}+\underbrace{24 \mathrm{~kJ}}_{\begin{array}{c}
\Delta G_{\text {clec. }} \\
(80 \%)
\end{array}} \approx 30 \mathrm{~kJ} \cdot \mathrm{mol}^{-1},
$$


where mol here refers to a mole of protons.

Now if we assume a temperature of $320 \mathrm{~K}$ (i.e., $47^{\circ} \mathrm{C}$, ten degrees higher than normal body temperature), and focusing only on the chemical term (ignoring the potential term since we do not know the functional dependence of the potential on the temperature at this point), the change in $\Delta G$ per proton would be then:

$$
\Delta \Delta G_{\text {chem. }}=\left(\Delta G_{320 \mathrm{~K}}-\Delta G_{310 \mathrm{~K}}\right)_{\text {chem. }}=2.3 \times 1 \times R \times 10 \times 1 \approx 0.2{\mathrm{~kJ} . \mathrm{mol}^{-1}},
$$

for a $\Delta \mathrm{pH}$ of one unit, which is a very small correction of the order of $3 \%$ of the chemical (minor) term. At this point we have no estimates of the effect of temperature on the dominant electrical term. As for temperature, $\mathrm{pH}$, and concentrations, and in view of the small physical space of the mitochondrial "capacitor", one must also account for the local and temporal fluctuation of the voltage and its associated electric field across the inner mitochondrial membrane [18, 19]. Furthermore, the obligatory energy dissipation by ATP synthase, a Maxwell demon as it acts as a molecular sorting machine [20-22], should be mildly revised as well whereby the minimum energy of $k_{\mathrm{B}} T \ln 2$ per proton crossing it should be increased by 10 $k_{\mathrm{B}} T \ln 2$ (which represents a correction of $\sim 3 \%$ at the most). Finally, perhaps one can also consider a minor aspect of a "heat engine" operation in the mitochondrion whereby one can add an energy term proportional to $\left[1-\left(T_{\text {cold }} / T_{\text {hot }}\right)\right]$.

None of the above considerations touch upon another crucial aspect that would be far more (exponentially) sensitive to a temperature difference and that is kinetics aspects. In fact, just from simple Arrhenius law, for a reaction with an activation energy of say $50 \mathrm{~kJ} / \mathrm{mol}$, the ratios of the rate constants' in the two extreme cases of $1^{\circ} \mathrm{C}$ temperature gradient $\left(37^{\circ} \mathrm{C} \rightarrow\right.$ $\left.38^{\circ} \mathrm{C}\right)$ and $10^{\circ} \mathrm{C}$ gradient $\left(37^{\circ} \mathrm{C} \rightarrow 47^{\circ} \mathrm{C}\right)$ would be bracketed by:

$$
\sim 1.06\left(\text { at } 38^{\circ} \mathrm{C}\right) \leq\left[\frac{k_{2}}{k_{1}}=e^{\frac{E_{a}}{R}\left(\frac{1}{T_{1}}-\frac{1}{T_{2}}\right)}\right] \leq \sim 1.83\left(\text { at } 47^{\circ} \mathrm{C}\right),
$$

implying an almost doubling of reactions (with $E_{\mathrm{a}}=50 \mathrm{~kJ} / \mathrm{mol}$ ) in the mitochondrion at the higher end of the temperature gradient scale, and a $6 \%$ rise in the rate of this reaction for a $1{ }^{\circ} \mathrm{C}$ gradient.

Nasr et al. have recently examined some of the biological consequences of a possible "hot mitochondrion" [3]. Among the problems that such a higher temperature mitochondrion is representing is that of the instability of mitochondrial macromolecules, particularly proteins and nucleic acids, at elevated temperatures as they can approach or reach their melting temperatures. This is further complicated by the known increase in reactive oxygen species (ROS) production at these higher temperatures (see Ref. [3] and references therein). Nasr et al. suggest that heat shock proteins (Hsps), abundant in the mitochondria and primarily thought to act as molecular chaperones to ensure the proper folding of imported proteins, may also act according to their conventional role as stabilizers of protein structures at higher temperatures. These Hsps can also have a secondary role as protectants against the temperature-dependent increase in ROS levels. These propositions are corroborated by the presence of other compatible solutes (known thermoprotectants and stabilizers of protein structures) such as di-myo-inoitol-1,1'-phosphate, and also by the richness of at least some mitochondrial nucleic acids encoding for Hsps in purine tracks compared to their cytosolic counterparts [3].

Purine tracks are long segments of a nucleic acid that have purine bases stacked one on the top of the next, and - given the larger aromatic rings of purines compared to pyrimidines this imparts added stability to these nucleic acids presumably to confront the hotter mitochondrial environment [3]. The very presence of these Hsps and their proposed role as structural stabilizers against the insults of the higher temperature argues in favor of the 
proposition that the mitochondrion could be indeed "hotter" than its surroundings, but the open question appears to be "by how much?"

Hotter or not, the fact remains that temperature must be maintained within a range that allows for the proper functioning of the mitochondrion. So the next question enquires on how the mitochondrion is capable of maintaining its thermal homeostasis? How does it regulate its temperature within an acceptable range? The authors are proposing a feedback mechanism for the regulation of the temperature of the mitochondrion [23].

The proposed control loop is based on the realization that the rate limiting step of the electron transport chain (ETC) is the lateral diffusion of ubiquinone/ol (in its various oxidation states, collectively referred to as "UQ" species) within the inner mitochondrial membrane $[24,25]$. An increase in the rate of heat production will be associated with a rise in the temperature of the mitochondrion, the higher temperature will decrease the viscosity of the membrane which, in turn, increases the diffusion coefficients of UQ. The faster mobility of UQ accelerates the electron transport chain, and as a result enhances the rate of proton pumping into the inter-membrane gap. The higher gradient created as a result will be associated with a stronger (chemiosmotic) electric field perpendicular to the membrane (and larger voltage across the inner mitochondrial membrane). As any capacitor, this electric field exerts a pressure $P$ over the capacitor dielectric medium (here the phospholipid membrane itself) according to:

$$
P=\frac{\varepsilon}{2} E^{2},
$$

where $\varepsilon$ is the dielectric constant of the membrane and $E$ is the magnitude of the electric field normal to the membrane.

This increase in the pressure on the membrane liquid crystal, in turn, increases its viscosity which reduces the diffusion coefficient of UQ putting the breaks on the further pumping of protons and of heat generation. The loop can operate in the opposite mode if the heat production is lower than optimal. This positive/negative feedback mechanism provides an explanation for the thermal homeostasis needed to maintain the mitochondrial temperature within working bounds.

\section{CONCLUSION}

Whether the mitochondrion is hotter than its surrounding remains debated. The literature appears to point to a hotter mitochondrion but with probably a lesser temperature gradient than suggested by Chrétien et al. The implications on the thermodynamic efficiency of the mitochondrion are, at best, a small perturbation and probably negligible within the biological context. However, and due to the exponential nature of Arrhenius equation, a small rise in temperature can have a considerable effect on the kinetics of the reactions of the Krebs cycle and of the electron transport chain.

\section{ACKNOWLEDGEMENTS}

The authors thank Professor Thank-Tung Nguyen Dang (Laval University), Professor Galina I. Dovbeshko (National Academy of Sciences of Ukraine), Professor Stephen L. Bearne (Dalhousie University), Professor Nagwa El-Badri (Zewail City of Science and Technology), and Professor Bohdan L. Luhovyy (Mount Saint Vincent University) for helpful discussions and suggestions. The authors also thank Dr. Anthonie W. Muller for his constructive comments at the proofs stage.

The authors are grateful to the Natural Sciences and Engineering Research Council of Canada (NSERC), the Canada Foundation for Innovation (CFI), Mount Saint Vincent University, Université Laval, and Saint Mary's University for financial and material support. 
The authors declare no conflicts of interest.

\section{Author's ORCID ID \\ Cherif Matta: (iD https://orcid.org/0000-0001-8397-5353}

\section{REFERENCES}

1. Siekevitz P. Powerhouse of the cell. Sci. Am. 1957;197(1):131-40.

2. Crescenzo R, Bianco F, Mazzoli A, Giacco A, Liverini G, Iossa S. Mitochondrial efficiency and insulin resistance. Front. Physiol. 2014;5:512. https://doi.org/10.3389/fphys.2014.00512

3. Nasr MA, Dovbeshko GI, Bearne SL, El-Badri N, Matta CF. Heat shock proteins in the "hot" mitochondrion: Identity and putative roles. BioEssays 2019;41(9):1900055. https://doi.org/10.1002/bies.201900055

4. Arai S, Suzuki M, Park SJ, Yoo JS, Wang L, Kang N-Y, Ha H-H, Chang Y-T. Mitochondria-targeted fluorescent thermometer monitors intracellular temperature gradient. Chem. Commun. 2015;51:8044-47. https://doi.org/10.1039/C5CC01088H

5. Chrétien D, Bénit P, Ha H-H, Keipert S, El-Khoury R, Chang Y-T, Jastroch M, Jacobs HT, Rustin P, Rak M. Mitochondria are physiologically maintained at close to $50^{\circ} \mathrm{C}$. PLOS Biology. 2018;16(1):e2003992. https://doi.org/10.1371/journal.pbio.2003992

6. Lane N. Hot mitochondria? PLOS Biology. 2018;16(1):e2005113. https://doi.org/10.1371/journal.pbio.2005113

7. Kim YK, Lee J-S, Bi X, Ha H-H, Ng SH, Ahn Y-H, Lee J-J, Wagner BK, Clemons PA, Chang Y-T. The binding of fluorophores to proteins depends on the cellular environment. Angew. Chem. Int. Ed. $2011 \mathrm{March}$ 11;50(12):2761-2763. https://doi.org/10.1002/anie.201007626

8. Baffou G, Rigneault H, Marguet D, Jullien L. A critique of methods for temperature imaging in single cells. Nat. Methods. 2014;11:899-901. https://doi.org/10.1038/nmeth.3073

9. Suzuki M, Zeeb V, Arai S, Oyama K, Ishiwata S. The $10^{5}$ gap issue between calculation and measurement in single-cell thermometry. Nat. Methods. 2015;12:802-803. https://doi.org/10.1038/nmeth.3551

10. Baffou G, Rigneault H, Marguet D, Jullien L. Reply to: "Validating subcellular thermal changes revealed by fluorescent thermosensors" and "The $10^{5}$ gap issue between calculation and measurement in single-cell thermometry". Nat. Methods. 2015;12:802-3. https://doi.org/10.1038/nmeth.3551

11. Sear RP. Diffusiophoresis in cells: A general nonequilibrium, nonmotor mechanism for the metabolismdependent transport of particles in cells. Phys. Rev. Lett. 2019 Mar 29;122(12):128101. https://doi.org/10.1103/PhysRevLett.122.128101

12. Shen L, Xie T-R, Yang R-Z, Chen Y, Kang J-S. Application of a dye-based mitochondrion-thermometry to determine the receptor downstream of prostaglandin E2 involved in the regulation of hepatocyte metabolism. Scient. Rep. 2018;8:13065. https://doi.org/10.1038/s41598-018-31356-y

13. Okabe K, Inada N, Gota C, Harada Y, Funatsu T, Uchiyama S. Intracellular temperature mapping with a fluorescent polymeric thermometer and fluorescence lifetime imaging microscopy. Nature Commun. 2012;3:705. https://doi.org/10.1038/ncomms1714

14. Hayashi T , Fukuda N, Uchiyama S, Inada N. A cell-permeable fluorescent polymeric thermometer for intracellular temperature mapping in mammalian cell lines. PLoS ONE. 2015 Feb 18;10(2):e0117677. https://doi.org/10.1371/journal.pone.0117677

15. Tsuji T, Yoshida S, Yoshida A, Uchiyama S. Cationic fluorescent polymeric thermometers with the ability to enter yeast and mammalian cells for practical intracellular temperature measurements. Anal. Chem. 2013;85: 9815-9823. https://doi.org/10.1021/ac402128f

16. Johnson HA. Thermal noise and biological information. Quarter. Rev. Biol. 1987;62:141-152.

17. Hickman J, Mishin Y. Temperature fluctuations in canonical systems: Insights from molecular dynamics simulations. Phys. Rev. B. 2016;94(18):184311. https://doi.org/10.1103/PhysRevB.94.184311

18. Procopio J, Fornes J. Fluctuations of the proton-electromotive force across the inner mitochondrial membrane. Phys. Rev. E. 1997;55(5):6285. https://doi.org/10.1103/PhysRevE.55.6285

19. Procopio J, Fornes JA. Fluctuation-dissipation theorem imposes high-voltage fluctuations in biological ionic channels. Phys. Rev. E. 1995 Jan;51(1):829-831. https://doi.org/10.1103/PhysRevE.51.829

20. Matta CF, Massa L. Notes on the energy equivalence of information. J. Phys. Chem. A 2017; 121(47):91319135. https://doi.org/10.1021/acs.jpca.7b09528

21. Matta CF, Massa L. Chapter 1: Information Theory and the Thermodynamic Efficiency of Biological Sorting Systems: Case Studies of the Kidney and of Mitochondrial ATP-Synthase. In: Bagchi D, editor. Sustained Energy for Enhanced Human Functions and Activity. The Netherlands: Elsevier; 2017. p. 3-29.

22. Matta CF, Massa L. Energy equivalence of information in the mitochondrion and the thermodynamic efficiency of ATP synthase. Biochemistry. 2015 Sep 1;54(34):5376-8. https://doi.org/10.1021/acs.biochem.5b00834 
A note on the consequences of a hot mitochondrion: some recent developments...

23. Fahimi P, Castanedo LAM, Nguyen-Dang T-T, Matta CF. Coupled electrical-thermal feedback control of the inner mitochondrial proton gradient. A hypothesis. Submitted for publication (2020).

24. Mathai JC, Sauna ZE, John O, Sitaramam V. Rate-limiting step in electron transport: Osmotically sensitive diffusion of quinones through voids in the bilayer. J. Biol. Chem. 1993 Jul 25;268(21):15442-54.

25. Moncelli MR, Herrero R, Becucci L, Guidelli R. Kinetics of electron and proton transfer to ubiquinone-10 and from ubiquinol-10 in a self-assembled phosphatidylcholine monolayer. Biochim. Biophys. Acta. 1998 May 27;1364(3):373-84. https://doi.org/10.1016/S0005-2728(98)00061-9 